\title{
Impact of Bee Pollination on Yield of Faba Bean (Vicia faba L.) Grown under Semi-Arid Conditions
}

\author{
Seif M. Gasim*, Awadalla A. Abdelmula \\ Department of Agronomy, Faculty of Agriculture, University of Khartoum, Shambat, Sudan \\ Email: *seif1963@gmail.com, *smgasim@uofk.edu, aabdelm63@yahoo.com, aabdelm63@uofk.edu
}

How to cite this paper: Gasim, S.M. and Abdelmula, A.A. (2018) Impact of Bee Pollination on Yield of Faba Bean (Vicia faba L.) Grown under Semi-Arid Conditions. Agricultural Sciences, 9, 729-740. https://doi.org/10.4236/as.2018.96051

Received: March 28, 2018

Accepted: June 23, 2018

Published: June 26, 2018

Copyright ( 2018 by authors and Scientific Research Publishing Inc. This work is licensed under the Creative Commons Attribution International License (CC BY 4.0).

http://creativecommons.org/licenses/by/4.0/

\section{(c) (i) Open Access}

\begin{abstract}
The effect of honeybee (Apis mellifera carnica) on yield was investigated in open-pollinated faba bean cultivars and three inbred generations produced from them (once-selfed, twice-selfed, and thrice-selfed). All entries were grown in cages under two pollination conditions: presence of bees (cross-pollination) or absence of bees (self-pollination). The open-pollinated generations gave the highest performance in the presence and absence of bees. In the presence of bees, the open-pollinated and their inbred entries gave higher performance in all of the studied traits than in the absence of bees; the average improvement in yield and its components was $22 \%$. The highest improvement percentage in yield performance was shown by more inbred entries (thrice-selfed $>$ once-selfed), indicating that in faba bean populations, the performance of inbred generations was chiefly associated with the tripping of flowers, which is usually governed by successfully fertilized flowers, i.e., plants result from selfing in faba bean population needs to be visited by pollinating insects (bees) to set more seeds. It concluded that honeybee has an important role in increasing faba bean yield in semi-arid conditions; hence, it is important to provide a pollinator friendly environment for their foraging places and nesting sites to secure food supply.
\end{abstract}

\section{Keywords}

Faba Bean, Yield, Honey Bees, Pollination, Self-Fertilization, Cross-Fertilization, Inbred-Generation

\section{Introduction}

Faba bean (Vicia faba L.) is a globally important grain legume crop due to its 
beneficial role in sustainable cropping [1] and rising requirements for plant protein as food and feed [2]. In Sudan, due to the recent increase in animal protein price, most of people shift towards less reliance on meat to supply their daily dietary protein from plant protein, especially faba bean [3], a situation that necessitates an increase in crop yield [4] [5]. Different from self-pollinated legumes, faba bean productivity is hindered by its reproductive mode [6] as the crop is partly self- and partly cross-pollinated species (mix-mating). Both self- and cross-pollination are carried out by pollinating insects (bees, bumble bees, etc.). Atypical visit of a pollinating insect to a flower can transfer foreign pollen and lead to out-crossing or facilitate own flower pollen and leads to self-pollination by disrupting (tripping) a physical barrier between the stigma and anthers that otherwise prevents self-pollination in some flowers [7]. In the absence of pollinators, only self-fertilization occurs [6] and this results in inbreeding depression and consequently low yield. On the other hand, in the presence of pollinators, cross-fertilization occurs and this is associated with heterosis and yield increase [6] [8] as well as improvement in seed quality [9] [10] [11] [12] and raising returns of the farmers. Bees play a vital role as pollinators for many horticultural crops (e.g. water melon, cucumber, strawberry, tomato, peeper, and eggplant, etc.) in the world and contribute to an increase in their yield performance and quality [13] [14] [15]. In faba bean, and in study carried out under two pollination conditions: self-pollination (where the plots were covered shortly before flowering using cages, $2 \mathrm{~mm}$ mesh size) and bee pollination conditions where beehives were introduced during the growing seasons near the plots and bees were left free-flying to carry out both self- and cross-pollination, [16] reported an increase in pod sets, seed per pods and seed yield in four faba bean genotypes and reported a yield increase of about $49 \%$ in bee-pollination condition compared to self-pollination (absence of bees). Moreover, [15] reported an average yield benefit of $17 \%$ in managed honey bee applied to faba bean in 17 fields in South Australia and observed a decrease in pods per plant field with increasing distance from hives.

In Sudan, as in most developing countries, farmers invest less input to manage pollination. They depend on the incidental pollination that is supported by the nearby ecosystems, mainly wild honeybees (Apis florea). The not managing pollination is mainly because of the lack of understanding of its economic value. Although most of faba bean cultivars grown in Sudan were reported to have a considerable degree of auto-fertility [17], yields are still far below their potential. Poor management practices, as well as the effect of abiotic (especially temperature) and/or biotic (diseases and pests) stresses, are listed among the causal factors, but no information is available on the influence of pollinators (bees) on faba bean yield. Here, we investigated on the effect of honey bee as pollinators on yield performance of faba bean crop grown under the semi-arid conditions of Sudan. 


\section{Materials and Methods}

\subsection{Genetic Material and Field Experiment}

The genetic material used consisted of five open-pollinated local Sudanese faba bean cultivars (differ mainly in seed size), namely, Hudeiba/93, Ed-damer, Selaim, Shabah and Bassabier, as well as three inbred generations [once-selfed (S1), twice-selfed (S2), and thrice-selfed (S3)] produced from each of them. These entries were investigated under irrigation condition at the Research Farm of the Faculty of Agriculture, Shambat (central of Sudan, Lat.: $150^{\circ} 40^{\prime} \mathrm{N}$, Longitude: $300^{\circ} 32^{\prime} \mathrm{E}$, and Altitude. of $380 \mathrm{~m}$ above sea level). The locality is in the semi-arid zone with hot summer $\left(38^{\circ} \mathrm{C}-42^{\circ} \mathrm{C}\right)$, a mild winter $\left(21^{\circ} \mathrm{C}-30^{\circ} \mathrm{C}\right)$ and short rainy -season (100 - $200 \mathrm{~mm}$ ) during summer (July-September).

Each genotype was grown in a plot of two ridges of $2 \mathrm{~m}$ length, $60 \mathrm{~cm}$ a part. One seed was planted/hole. The spacing between the holes along the ridge was $10 \mathrm{~cm}$. The sowing was in the $1^{\text {st }}$ week of November during the winter seasons of 2013/2014 and 2014/2015. A nested type of complete block design with two replicates (inbred lines were nested within the replicates) was used to conduct the experiment.

\subsection{Pollination Condition}

For pollination effect, the genotypes were tested under two pollination conditions: 1) self-pollination and 2) bee-pollination. Immediately prior flowering, the experimental area was covered with two net cages of $6 \times 20 \mathrm{~m}$ each, $2 \mathrm{~mm}$ mesh size). For bee pollination, a beehive ( 5 combs) of a local honey-bee (Apis mellifer acarnica) was introduced inside the cage at the beginning of the flowering period, where both self- and cross-pollination can take place; about 5000 - 6000 bees were used per hive; hives were left inside the age till the end of the flowering period. For self-pollination, no beehive was used. The experiment was irrigated every 14 days and well weeded before flowering. At maturity, the cages were removed and data were collected on yield (yield/plant in gram) and yield components: number of pods/plant, number of seeds/pod, number of seeds/plant, 100 -seed weight and yield/plant. Ten plants per experimental unit per replicate (excluding the plants from the two sides of the ridges) were used to estimate yield (yield/plant) and yield components. The yield/plant was estimated by weighing the seed of the 10 plants per replicate and then statistically analyzed as described for the nested type of a randomized complete block design using the computer program PLABSTAT [18].

The relative improvement percentage due to bee pollination for each trait was estimated as follows:

$$
\text { Improvement percentage }=\left[\left(P_{+}-P_{-}\right) / P_{+}\right] \times 100
$$

where, $P_{+}=$mean performance in the presence of bees

$P_{-}=$mean performance in the absence of bees 


\section{Results}

Analysis of variance was carried out for the effect of pollination condition, genotypes and genotype $\mathrm{x}$ pollination condition interaction on yield and its components for all of the twenty entries (Table not shown) and for the effect of these factors in the open-pollinated (OP) genotypes and their inbred generations (Table 1). The results showed significant differences due to the effect of pollination condition and genotypes in all traits. However, the effect of pollination condition $\mathrm{x}$ genotype interaction was not significant for all traits. Open-pollinated genotypes and their inbred generations exhibited great variability for the effect of bee pollination on the performance of the studied traits (Table 1). Generally, in the presence of bee pollination, open-pollinated cultivars and their inbred generations exhibited higher performance in the studied traits than in the absence of bee pollination. As a result of bee pollination, the improvement in traits performance was higher in inbred generations compared to the open-pollinated ones. On the hand, the performance of all traits was decreased after every other generation of selfing (Table 2).

Table 1. Analysis of variance for five studied traits in open-pollinated (OP) genotypes and their three inbred generations (S1, S2 and S3).

\begin{tabular}{|c|c|c|c|c|c|}
\hline Sources of variation & d.f & OP & S1 & $\mathrm{S} 2$ & S3 \\
\hline \multicolumn{6}{|l|}{ 1) Number of pods/plant } \\
\hline Pollination condition $(\mathrm{P})$ & 1 & 2.3 & $56.89^{\star *}$ & $46.48^{\star *}$ & $31.40^{\star *}$ \\
\hline Entries (E) & 3 & $37.86^{\star *}$ & $4.09^{\star}$ & $6.91^{\star}$ & 2.75 \\
\hline PX E & 3 & 2.10 & 0.89 & 1.05 & 0.26 \\
\hline Error & 6 & 1.68 & 1.8 & 1.78 & 2.21 \\
\hline \multicolumn{6}{|l|}{ 2) Number of seeds/pod } \\
\hline Pollination condition $(\mathrm{P})$ & 1 & $11.21^{\star *}$ & $52.09^{\star *}$ & $31.07^{\star *}$ & $12.92^{\star *}$ \\
\hline Entries (E) & 3 & 3.39 & 2.78 & 2.39 & 1.32 \\
\hline PX E & 3 & 1.12 & 1.48 & 3.04 & 0.57 \\
\hline Error & 6 & 0.93 & 0.43 & 3.63 & 1.57 \\
\hline \multicolumn{6}{|l|}{ 3) Number of seeds/plant } \\
\hline Pollination condition $(\mathrm{P})$ & 1 & $36.29^{\star *}$ & $59.53^{\star *}$ & $13.67^{\star *}$ & $7.05^{\star *}$ \\
\hline Entries (E) & 3 & $45.16^{\star *}$ & $99.50^{\star *}$ & $14.23^{\star *}$ & $9.26^{\star *}$ \\
\hline PX E & 3 & 2.44 & 1.10 & 1.20 & 1.06 \\
\hline Error & 6 & 70.56 & 19.24 & 84.70 & 78.21 \\
\hline \multicolumn{6}{|l|}{ 4) 100 -seed weight } \\
\hline Pollination condition $(\mathrm{P})$ & 1 & $1.87^{\star}$ & $16.90^{\star *}$ & $63.89^{\star *}$ & $13.73^{\star *}$ \\
\hline Entries (E) & 3 & $399.30^{\star *}$ & $485.71^{\star *}$ & $664.32^{\star *}$ & $222.02^{\star *}$ \\
\hline PX E & 3 & 0.78 & 2.33 & 2.39 & 1.76 \\
\hline Error & 6 & 28.28 & 26.54 & 17.91 & 36.76 \\
\hline \multicolumn{6}{|l|}{ 5) Yield/plant } \\
\hline Pollination condition $(\mathrm{P})$ & 1 & $31.18^{\star *}$ & $87.81^{\star *}$ & $27.64^{\star *}$ & $9.86^{* *}$ \\
\hline Entries (E) & 3 & $7.98^{\star *}$ & $44.37^{\star \star}$ & $6.17^{\star}$ & $6.47^{\star}$ \\
\hline PX E & 3 & 0.32 & 1.20 & 1.38 & 0.35 \\
\hline Error & 6 & 42.27 & 8.40 & 26.36 & 30.42 \\
\hline
\end{tabular}

${ }^{\star}$ Significant at $0.05 ;{ }^{\star *}$ Significant at 0.10 . 
Table 2. Mean performance of yield traits for open-pollinated (OP) and inbred generations (S1, S2 and S3) of faba bean in bee-pollination and self-pollination (no bees) conditions.

\begin{tabular}{|c|c|c|c|c|c|c|c|c|}
\hline \multirow{2}{*}{ Trait/genotype } & \multicolumn{2}{|c|}{$\mathrm{OP}$} & \multicolumn{2}{|c|}{ S1 } & \multicolumn{2}{|c|}{ S2 } & \multicolumn{2}{|c|}{ S3 } \\
\hline & + & - & + & - & + & - & + & - \\
\hline Number of pods/plant & 10.92 & 10.03 & 9.10 & 7.50 & 7.40 & 5.80 & 4.61 & 3.22 \\
\hline Overall mean & \multicolumn{2}{|c|}{10.48} & \multicolumn{2}{|c|}{8.30} & \multicolumn{2}{|c|}{6.6} & \multicolumn{2}{|c|}{3.92} \\
\hline Improvement \%age ) & \multicolumn{2}{|c|}{$8 \%$} & \multicolumn{2}{|c|}{$18 \%$} & \multicolumn{2}{|c|}{$22 \%$} & \multicolumn{2}{|c|}{$30 \%$} \\
\hline LSD (\%) & \multicolumn{2}{|c|}{0.94} & \multicolumn{2}{|c|}{0.49} & \multicolumn{2}{|c|}{0.49} & \multicolumn{2}{|c|}{0.53} \\
\hline Number of seeds/pod & 2.99 & 2.49 & 2.30 & 1.74 & 1.85 & 1.34 & 1.44 & 0.95 \\
\hline Overall mean & \multicolumn{2}{|c|}{2.74} & \multicolumn{2}{|c|}{2.02} & \multicolumn{2}{|c|}{1.59} & \multicolumn{2}{|c|}{1.16} \\
\hline Improvement $\%$ age & \multicolumn{2}{|c|}{$17 \%$} & \multicolumn{2}{|c|}{$24 \%$} & \multicolumn{2}{|c|}{$28 \%$} & \multicolumn{2}{|c|}{$34 \%$} \\
\hline $\operatorname{LSD}(5 \%)$ & \multicolumn{2}{|c|}{0.35} & \multicolumn{2}{|c|}{0.24} & \multicolumn{2}{|c|}{0.24} & \multicolumn{2}{|c|}{0.24} \\
\hline Number of seeds/plant & 33.48 & 27.98 & 27.29 & 21.72 & 24.13 & 16.75 & 16.18 & 10.38 \\
\hline Overall mean & \multicolumn{2}{|c|}{30.71} & \multicolumn{2}{|c|}{24.51} & \multicolumn{2}{|c|}{20.44} & \multicolumn{2}{|c|}{13.28} \\
\hline Improvement age $\%$ & \multicolumn{2}{|c|}{$16 \%$} & & & & & & \\
\hline $\operatorname{LSD}(5 \%)$ & & & & & & & & \\
\hline 100 -seed weight (g) & 60.14 & 56.74 & 58.21 & 52.83 & 56.78 & 50.32 & 55.74 & 47.38 \\
\hline Overall mean & & & 55 & & & & & \\
\hline Improvement age $\%$ & & & & & & & & \\
\hline LSD (5\%) & & & & & & & & \\
\hline Yield/plant (g) & 24.54 & 21.39 & 20.46 & 15.53 & 16.94 & 12.12 & 12.13 & 7.34 \\
\hline Overall mean & & & 17 & & & & & \\
\hline Improvement age $\%$ & & & & & & & & \\
\hline LSD (5\%) & & & 1. & & & & & \\
\hline
\end{tabular}

+: bee pollination (bees); -: self-pollination (no bees).

On average, the relative improvement in number of pods/plant in the presence of bees was $20 \%$; it was $8 \%$ in open-pollinated generation, $18 \%$ for $\mathrm{S}_{1}, 22 \%$ for $\mathrm{S}_{2}$ and reached $30 \%$ for $\mathrm{S}_{3}$ generation. The highest number of pods/plant was obtained by OP generations of Hudeiba/93 in the presence of bee pollination and the lowest was registered for $\mathrm{S}_{3}$ generation of Seliam in the absence of bee pollination (Figure 1(a)). The average improvement in number of seeds/pod due to bee pollination was $26 \%$. The importance of bee pollination in improvement of the performance of this trait started to increase with increasing degree of selfing from $17 \%$ in $S_{1}, 24 \%$ in $S_{2}$ and reached up to $34 \%$ in $S_{3}$ generation (Table 2). The open-pollinated generation of Bassabier exhibited the highest number of seeds/pod in the presence of bees and the lowest number of seeds/pod was recorded in $\mathrm{S}_{3}$ generation of Shabah in the absence of bees (Figure 1(b)). 


(III




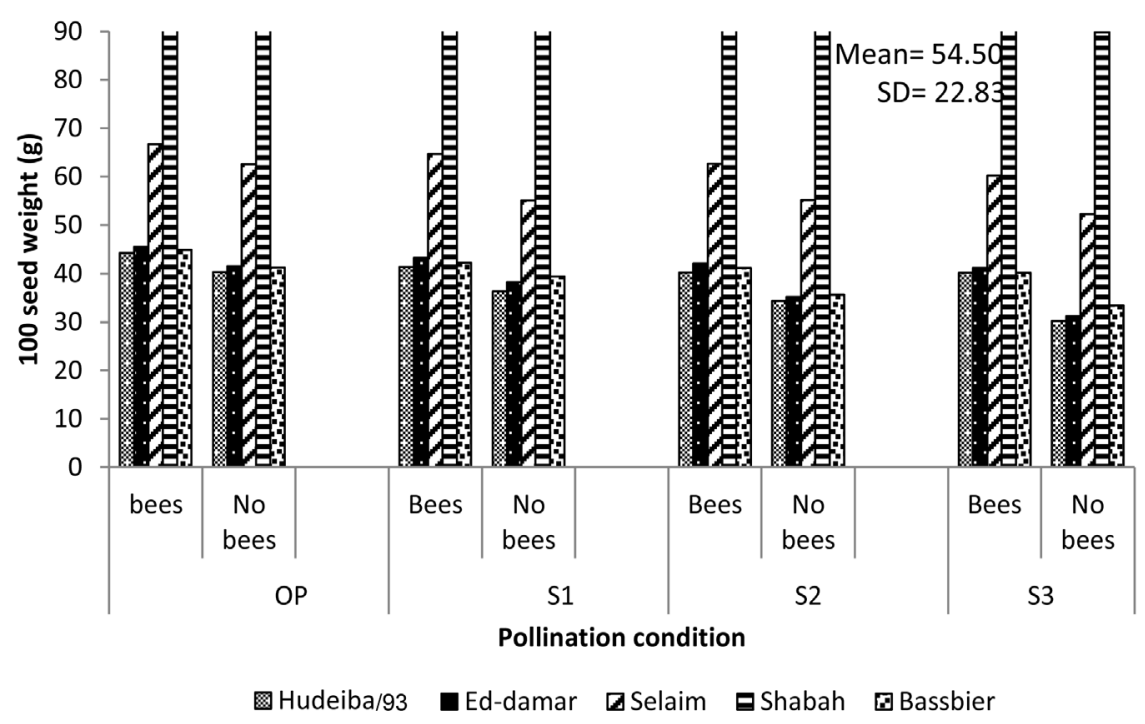

(d)

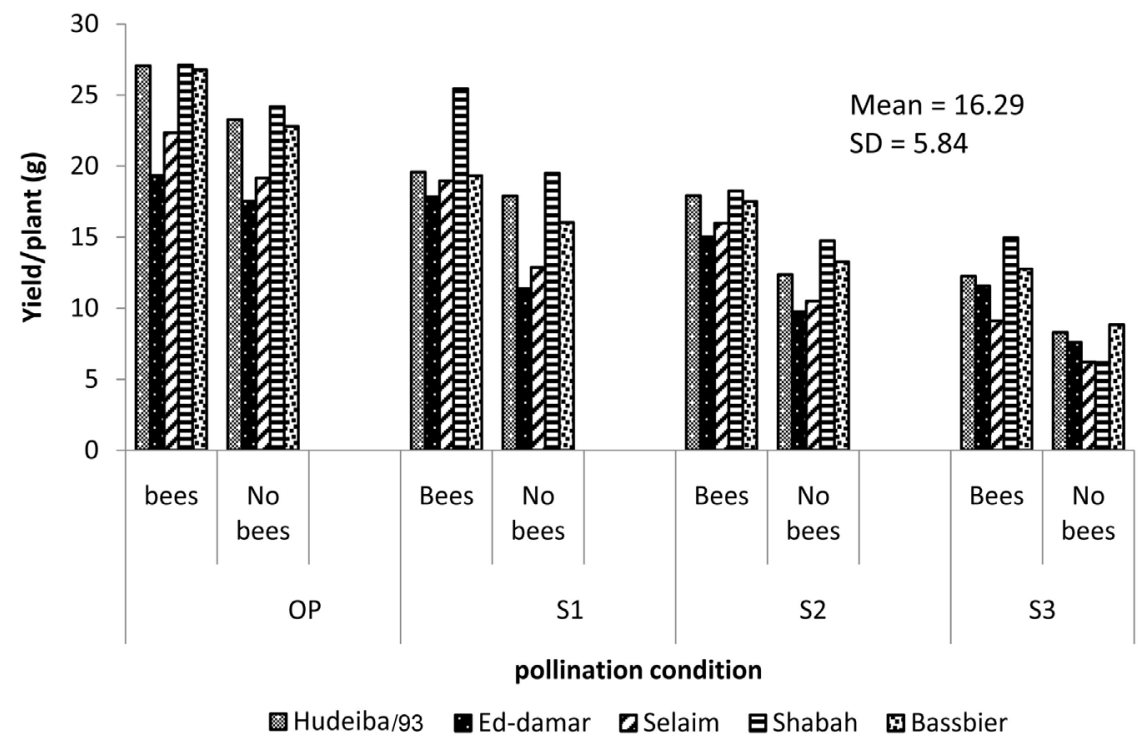

(e)

Figure 1. Mean performance of yield traits of five faba bean open-pollinated genotypes (OP) their inbred generations $\left(\mathrm{S}_{1}, \mathrm{~S}_{2}\right.$, and $\left.\mathrm{S}_{3}\right)$ in the presence of bees (bee-pollination) and absence of bees (self-pollination).

The average improvement in number of seeds/plant and 100-seed weight due to bee pollination was $26 \%$ and $11 \%$, respectively; the improvement in number of seed/plant ranged from $16 \%$ in $\mathrm{S}_{1}$ to $36 \%$ in $\mathrm{S}_{3}$ (Table 2). The highest number of seeds/plant was recorded by the open-pollinated generation of Bassabier, whereas the $\mathrm{S}_{3}$ generation of Sahaba gave the lowest number of seeds/plant (Figure 1(c)). The trait of 100-seed weight was the least trait to be affected by bee pollination (Table 2 and Figure 1(d)); however, the improvement due to the effect of bee pollination was increased from $7 \%$ in the open-pollinated to $15 \%$ in $\mathrm{S}_{3}$ generation. The open-pollinated generation of Shabah gave the highest 
100-seed weight and $S_{3}$ generation of Hudeiba/93 gave the lowest 100-seed weight (Figure 1(d)). The average improvement of yield/plant was $25 \%$. It was $7 \%$ in $S_{1}$ for the open-pollinated generation, $24 \%$ for $S_{1}$ and reached $39 \%$ in $S_{3}$ (Table 2). The open-pollinated generation of Shabah gave the highest yield/plant in the presence of bees in open pollinated generation and lowest yield/plant in $\mathrm{S}_{3}$ generation (Figure $1(\mathrm{e})$ ). The overall average improvement of bee pollination in yield and its component was $22 \%$.

However, the imitation of the present study is that: we did count the number of bee visits per day as well as the number of pollinators/experimental unit needed per hectare to determine the exact number of beehives to be used in large scale faba bean filed as the bees (Apis mellifer acarnica) was a bit aggressive. Moreover, the environmental factors such as the degree of temperature and relative humidity inside the hives, which may affect the activity of the bees, were not measured. In addition, the study did not consider the effect of pollination under natural field conditions that made by Apis florea as it may have a role in faba bean yield.

\section{Discussion}

In many crop species, there is a positive correlation between the value of a crop per production unit and vulnerability based on its dependence on insect pollination, which is particularly true for Vicia faba L. In the present study, the significant effect of pollination conditions on different traits indicated the importance of bee pollination on faba bean yield [16] [19] as pollinators can carry out both self-fertilizations by tripping and out-crossing when they visit other flowers of the other plants. Therefore, they have potential to increase yield and its components in faba bean [10]. In faba bean, the open-and self-pollinated plants are used by faba bean breeders in a kind of pedigree breeding scheme, the resulting population genotypes are genetically heterogeneous and heterozygous to varying degrees. As a consequence, different levels of heterosis are expected in the open-pollinated genotypes, thus giving rise to varietal differences in sensitivity to inbreeding [20] [21]. Therefore, in the present study, the performance of the inbred lines was less than the open-pollinated genotypes from which they were derived. This because, when pollinators are absent, seeds are the result of auto-fertility. However, faba beans Sudanese faba bean genotypes are generally have high degree of autofertility, but depend on tripping to produce high yield. Generally, in faba bean and without being tripped seed set may vary from zero to $100 \%$ depending on the genotype, its inbreeding status and partly on environmental conditions [6]. High level of inbreeding favors low level of autofertility, hence bee pollination is needed for pod and seed setting. As a consequence of the absence of pollinators, yield of pure self-seed in cages is variable and mostly low [6]. Moreover, the non-significant differences in pollination condition $\mathrm{x}$ genotypes interaction indicate the non-preference of bees to visit a specific genotype. 
In the present investigation, the non-significant variation in number of pods/plant in the open-pollinated genotypes in the presence of bee pollination and the significant variation among their inbred generation verify the presence of autofetrility in the open-pollinated generation [17]. Since the importance of bee pollination for seed yield is chiefly associated with tripping of lowers, the number of pods/plant is usually governed by successfully fertilized flowers so this trait exhibited significance variations among inbred lines (18\% in $\mathrm{S}_{1}$ to $30 \%$ in $\mathrm{S}_{3}$ ). The reduction in number of pods/plant in inbred generations indicates the importance of bee pollination in pod setting. Moreover, the pods of the self-pollinated plants were observed to ripen late (data not shown) with their green intact leaves and this provides a visible evidence of the importance of the bee pollination for seed setting and early ripening. Hence, inadequate pollination reduces and delays seed setting and prolongs vegetative development and flowering period [22].

In the present study, the bee pollinated plants were found to produce more pods/plant and more seeds/pod than the self-pollinated plants. The number of seeds/pod is governed by successfully fertilized ovules; the number of both flowers and ovules that are formed always greatly exceeds the resulting number of pods and seeds that are produced [23]. A part from possible tripping effect, the difference in the number of seeds/pod was influenced by late seed setting in self-pollinated plants compared to bee pollinated ones. Moreover, the bee pollinated plants were observed to set more pods on the lower nodes and ripen earlier and with more seeds/pod than those without bees (data not shown). Similar results were reported [16] [24] [25] indicating that bee pollination improved fertilization and enable allocation more pods in the lower nodes [10] [23] [26]. The increase in yield/plant under bee pollination condition than those under self-pollinated condition could be attributed primarily to more pods/plant and number of seeds/pod in the earlier case. On the other hand, the reductions in performance of bean plants in self-generated entries proved the importance of bee pollination in the plants resulted from self-fertilization as reported by many workers [27] [28], and that is why in the open-pollinated conditions faba bean yield fluctuated from year to year as the bean population plants are in different degree of self-fertilization. The overall average improvement in performance due to bee pollination in the present work, as demonstrated in Figure 2, was 22\%, which is similar to the other studies comparing faba bean performance in controlled conditions with and without insect pollinators e.g., 25\% [24] and 26\% [10].

\section{Conclusion}

Based on the present study, it could be concluded that honeybees (Apis mellifer acarnica) are effective pollinators in the areas of semi-arid climate; thus providing faba bean field with beehives, plants will set more pods/plant, seeds/pod, seeds/plant and yield/plant and this will consequently give more faba bean 


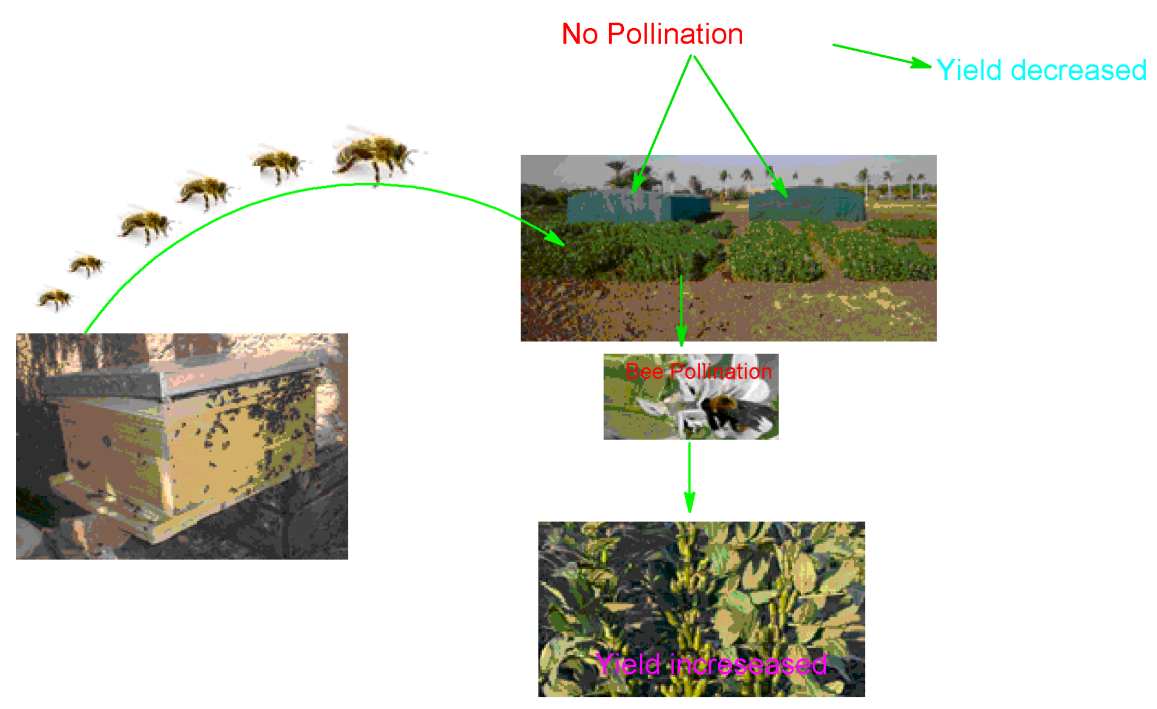

Figure 2. The overall effect of bee pollination on faba bean yield.

yield/unit area $(\mathrm{Kg} / \mathrm{ha})$. The improvement in performance of the inbred plants in the presence of bees and their low performance in the absence of bees indicated their dependence on pollinators visit to set pods and seeds. More research is needed on conservation and enhancement of populations of honeybees to overcome the threats of the climate change, extreme weather of the semi-arid, especially high temperature and cultural practices associated with the application of pesticides that impend the ability of bees to navigate or forage.

\section{References}

[1] Köpke, U. and Nemecek, T. (2010) Ecological Services of Faba Bean. Field Crop Research, 115, 217-233. https://doi.org/10.1016/j.fcr.2009.10.012

[2] Tilman, D., Balzer, C., Hill, J. and Befort, B.L. (2011) Global Food Demand and the Sustainable Intensification of Agriculture. Proceeding of the National Academy of Sciences of the United States of America, 108, 20260-20264. https://doi.org/10.1073/pnas.1116437108

[3] Gasim, S., Solafa, A., Abdelmulla, A. and Isam, A. (2015) Yield and Yield Quality Attributes of Faba Bean Lines Grown under Marginal Environmental Conditions of Sudan. Food Science and Nutrition, 3, 539-547.

https://doi.org/10.1002/fsn3.245

[4] Salih, S.H., Ageeb, O.A., Saxena, M.C. and Solh, M.B. (1996) Production and Improvement of Cool-Season Food Legumes in the Sudan. Proceeding of the National Research Review Workshop, Wad Medani, 27-30 August 1995, 250 p.

[5] Gasim, S., Hejien, H., Khalifa, J. and Abdelmula, A. (2013) Effect of Self-Fertilization on Performance, Breeding and Germplasm Management of Four Local Faba Bean Cultivars. Journal of Agricultural Science Technology B, 3, 182-188.

[6] Link, W. (1990) Autofertility and Rate of Cross-Fertilization: Crucial Characters for Breeding Synthetic Varieties in Faba Bean (Vicia faba L.). Theoretical and Applied Genetics, 79, 713-717. https://doi.org/10.1007/BF00226888

[7] Kambal, A.E., Bond, D.A. and Toynbee-Clarke, G. (1976) A Study on the Pollination Mechanism in Field Beans (Vicia faba L.). Journal of Agricultural Sciences 
Cambridge, 87, 519-526. https://doi.org/10.1017/S0021859600033128

[8] Gasim, S., Abel, S. and Link, W. (2004) Extent, Variation and Breeding Impact of Natural Cross-Fertilization in German Winter Faba Beans Using Hilum Colour as Marker. Eupytica, 136, 193-200. https://doi.org/10.1023/B:EUPH.0000030669.75809.dc

[9] Bond, D.A. and Poulsen, M.H. (1983) Pollination. In: Hebblethwaite, P.D., Ed., The Faba Bean (Vicia faba L.), Butterworths, London, 77-101.

[10] Somerville, D.C. (1999) Honeybees (Apis mellifera L.) Increase Yields of Faba Beans (Vicia faba L.) in New South Wales While Maintaining Adequate Protein Requirements from Faba Bean Pollen. Australian Journal of Experimental Agriculture, 39, 1001-1005. https://doi.org/10.1071/EA99023

[11] Carré, G., Roche, P., Chifflet, R., Morison, N., Bommarco, R., Harrison-Cripps, J., Krewenka, K., Potts, S.G., Roberts, S.M.P., Rodet, G., Settele, J., Steffan-Dewenter, I., Szentgyorgyi, H., Tscheulin, T., Westphal, C., Woyciechowski, M. and Vaissière, B.E. (2009) Landscape Context and Habitat Type as Drivers of Bee Diversity in European Annual Crops. Agricultural Ecosystem Environment, 133, 40-47. https://doi.org/10.1016/j.agee.2009.05.001

[12] Singh, A.K., Baharati, R.C., Manibhushan, N.C. and Pedpati, A. (2013) An Assessment of Faba Bean (Vicia faba L.) Current Status and Future Prospect. African Journal of Agricultural Research, 8, 6634-6641.

[13] Williams, J.H. (1994) The Dependence of Crop Production within the European Union on Pollination by Honeybees. Agricultural Zoology Review, 6, 229-257.

[14] James, R. and Pitts-Singer, J. (2008) Bee Pollination in Agricultural Ecosystems. Oxford University Press, Oxford, 284 p. https://doi.org/10.1093/acprof:oso/9780195316957.001.0001

[15] Saul, A.C. and Danny, F. (2013) Significant Yield Benefits from Honeybee Pollination of Faba Bean (Vicia faba) Assessed at Field Scale. Field Crops Research, 149, 269-275. https://doi.org/10.1016/j.fcr.2013.05.019

[16] Musallam, I.W., Haddad, N.J., Tawaha, A.M. and Migdadi, O.S. (2004) The Importance of Beepollination in Four Genotypes of Faba Bean (Vicia faba L.). International Journal of Agriculture and Biology, 6, 9-11.

[17] Gasim, S., Abdelmula, A. and Khalifa, J. (2011) Analysis of the Degree of Cross-Fertilization and Autofertility and Their Impact on Breeding Faba Bean ( $\mathrm{Vi}$ cia faba L.) Cultivars. African Journal of Agricultural Research, 6, 6387-6390.

[18] Utz, H.F. (1997) Computer Program for Statistical Analysis for Plant Breeding Experiments. Version 2N, Institute of Plant Breeding, Seed Science and Population Genetics, University of Hohenheim, Hohenheim.

[19] Aouar-Sadli, M., Louadi, K. and Doumandji, S.E. (2008) Pollination of the Broad Bean (Vicia faba L. var. Major) (Fabaceae) by Wild Bees and Honey Bees (Hymenoptera: Apoidea) and Its Impact on the Seed Production in the Tizi-Ouzou Area (Algeria). African Journal of Agricultural Research, 3, 266-272.

[20] Nadal, S., Suso, M.J. and Moreno, M.T. (2003) Management of Vicia faba Genetic Resources: Changes Associated to the Selfing Process in the Major, Equina and Minor Groups. Genetic Resources and Crop Evolution, 50, 183-192. https://doi.org/10.1023/A:1022944017530

[21] Gasim, S. and Link, W. (2007) Agronomic Performance and the Effect of Self-Fertilization on German Winter Beans. Journal of Central European Agriculture, 8, 121-127. 
[22] Poulsen, M.H. (1975) Pollination, Seed Setting, Cross-Fertilization and Inbreeding in Vicia faba L. Zeitschrift für Pflanzenzüchtung, 74, 97-118.

[23] Suso, M.J., Moreno, M.T., Mondragao-Rodrigues, F. and Cubero, J.J. (1996) Reproductive Biology of Vicia faba: Role of Pollination Conditions. Field Crop Research, 46, 81-91. https://doi.org/10.1016/0378-4290(95)00089-5

[24] Algiaamdi, A. and Algamdi, S. (2003) The Impact of Insect Pollination on Yield and Yield Componenets of Faba Bean (Vicica faba L.). Saudi Journal of Biological Science, 10, 56-63.

[25] Garratt, M.P.D., Coston, D.J., Truslove, C.L., Lappage, M.G., Dean, R., Biesmeijer, J.C. and Potts, S.G. (2014) The Identity of Crop Pollinators Help Target Conservation for Improved Ecosystems Services. Biological Conservation, 169, 128-135. https://doi.org/10.1016/j.biocon.2013.11.001

[26] Bishop, J., Jones, H.E., Lukac, M. and Potts, S.G. (2016) Insect Pollination Reduces Yield Loss Following Heat Stress in Faba Bean (Vicia faba L.). Agriculture, Ecosystem and Environment, 220, 89-96. https://doi.org/10.1016/j.agee.2015.12.007

[27] Free, J.B. (1993) Insect Pollination of Crops. Academic Press, London, 684 p.

[28] Bond, D.A. and Kirby, E.J.M. (2001) Pollination of Autumn-Sown Broad Bean ( Vicia faba var. major) by the Solitary Bee (Anthophora plumipes). Grain Legume, 32, 8-9. 